\title{
Board Capitals, R\&D and Leverage Strategies on Financial Performance
}

\author{
Li-Jen Yeh \\ Department of Finance, Shih Chien University, Taiwan
}

Hsien-Chang Kuo

College of Management and Design, Ming Chi of Technology, Taiwan

Received: February 25, 2021 Accepted: March 27, 2021 Published: April 1, 2021

doi:10.5296/ber.v11i2.18482ＵRL: https://doi.org/10.5296/ber.v11i2.18482

\begin{abstract}
Exactly how corporate boards influence their firms' performance remains a puzzle. We construct a mediational model to observe the paths that board capitals affect firm's key strategies (as R\&D and leverage). Furthermore, we can estimate the direct and mediational influent level of board capitals on financial performance.

For confirming those hypotheses in our study, the financial data of listed companies in Taiwan and Mainland China are collected. This study confirms that the education level and seniority of firm's directors significantly influence the R\&D intensity and financial leverage of corporates, furthermore affect firm performance. This mediational effects from $\mathrm{R} \& \mathrm{D}$ intensity and debt ratio are estimated about 22.31\% 35.65\% in Taiwan, and $25.46 \% \sim 39.47 \%$ in Mainland China. We also find that the higher education level and the less seniority of the Boards lead to the more R\&D intensity and the less debt ratio, then the better financial performance.
\end{abstract}

Keywords: Board capitals, R\&D intensity, Debt ratio, Mediational effects, Financial performance

\section{Introduction}

Board capital is the intangible concept introduced in a study by Hillman and Dalziel (2003). They defined board capital as "the sum of the human and social capital of the board of directors, and a proxy for the boards' ability to provide resources to the firm". That is, the board of directors own specific knowledge and resources required by organization, that have been the center of company's long-term decision-making and enterprise control system, 
simultaneously plays an important role in the field of enterprise's research and development and decision-making of corporate leverage.

Basically, the boards' human traits, such as academic qualifications, seniority, etc. are important human resource bases. It is a pivotal decision factor in the innovations needed for the future growth of the company, as well as the necessary financing decisions for the operation of the enterprise. In other words, the quality of "manpower" at the top of the company will affect the "innovation" of the company's development and the "financial fund" needed, and then result into a very different business performance. The theory of resource dependency also holds that the personal characteristics of CEO and board supervisors will affect the company's investing decision and company value (Kuo et al., 2016; 2018).

Gottesman and Morey (2006) suggested that the education level of senior executives is an important proxy variable of intelligent capital. On the other hand, the tenure of Board members and business performance also present a rich and heterogeneous special relationship. Once the length of term behaves the index to the ability of board members adapting to business management; the longer term indicates that the board members is more adaptive to the enterprise, and with the increase in seniority, board members quickly accumulate the enterprise's important market knowledge and ability, and provide important judgements for enterprises (Kor and Sundaramuthy, 2009; Brookman and Thistle, 2009). Darmadi (2013) introduced other control variables, including enterprise size and family control, to further test the relevance of educational attainment to corporate financial performance; the empirical findings show senior enterprise managers (including board supervisor and CEO) with higher education level have significant positive benefits for business management, and their degrees from prestigious university have significantly better influence on the financial performance. The empirical results of Kuo et al. (2018) show that having a high level of education for the CEO and board members benefits the company's value enhancement.

However what paths do the chairperson's personal traits (such as academic leadership and seniority leadership traits) influence the enterprise's performance with? In order to answer these questions, this study collects corporate governance and financial performance data of listed companies from Taiwan Stock Exchange, Taipei Exchange, Shanghai Stock Exchange, and Shenzhen Stock Exchange during 2012 to 2017, to empirically observe the influential paths by education level and seniority of board of director members. The listed companies of the two regions are representative of the management culture of Sinitic enterprises, the economic development and industrial characteristics are very different, especially in terms of the relationship between corporate financial performance and $R \& D$ input or financing decisions.

Through derivation of mediational model, this study introduces mediator variables of R\&D strength and debt ratio in order to observe if the human traits of board members influence $R \& D$ decisions and financing decisions of the enterprise, then such decisions further influence financial performance. Through empirical data, this study can significantly verify the above, i.e. modifying education level and seniority of the members of the board of directors can help to increase corporate financial performance. 


\section{MInstitute Macrothink $_{\text {Ins }}$}

Business and Economic Research

ISSN 2162-4860

2021, Vol. 11, No. 2

The result also indicates that, for listed firms in the Taiwan area, higher R\&D intensity or lower financial leverage correlate with better financial performance, especially in the high-tech sectors, higher seniority of the chairperson, higher education level of the chairperson, and lower seniority of board members increase R\&D intensity and decrease debt ratio, increasing financial performance. While for listed firms in the mainland China, higher R\&D intensity or lower financial leverage correlate with financial performance. Among them, higher seniority of board members (including the chairperson) and higher standard deviation for education level increase $R \& D$ intensity, and further lead to increase in financial performance.

The remaining sections of this study are as follows: the second section is a review on relevant literatures and empirical hypotheses which discuss the influences of the education level and seniority of board chairperson and board members on financial performances, and through the mediational effects of R\&D intensity and debt ratio to establish the hypothesis for this study. The third section is model's design, which explains the relevant models for this study. The fourth section tests the mediational effects of R\&D intensity and debt ratio. The fifth section discusses the influence of board chairperson, we observe how the human traits of the leaders affect $R \& D$ inputs and financial leverage decisions, which lead to further influence on financial performance. Finally, the sixth section concludes this study.

\section{Literature Review and Research Hypothesis}

Those literatures in the field of corporate governance often describe the importance of the link between boards of directors and company performance. They also point out that there is a positive relationship between the degree of corporate governance and its financial performance (Jensen and Meckling, 1976; Chen et al., 2004; Kuo et al., 2018). Based on those view, the degree of implementation of corporate governance is closely related to the characteristics of the board of directors, especially in terms of ownership structure. Different types of ownership structure lead to different effects for shareholders to exercise their power, which further influences the business performance. Therefore, ownership structure is a key factor in corporate governance (Jensen and Meckling, 1976; Morck et al., 1988).

In recent studies, intellectual capital is gaining visibility as an important resource for business operation. Gottesman and Morey (2006) suggested that the education degree of high-level managers is an important proxy variable for intellectual capital. Mahadeo et al. (2012) empirically analyzed emerging market countries and found that multidisciplinary educational backgrounds are significantly correlated with firm performance. On the other hand, the tenure length also has diverse and heterogeneous special relationship with firm performance. Longer tenure indicates that the board member is more adapted to the business. With the increase of tenure length, the board member would increasingly accumulate knowledge and capability related to the business, and provide important decisions for the firm (Kor and Sundaramuthy, 2009; Brookman and Thistle, 2009), but too long tenure of CEO to reduce passion for work, even cause numerous agency problems. Darmadi (2013) introduced other control variables (e.g. firm size and family control) to further examine the correlation between education level and firm financial performance. Based on the views above, this study suggests that the human 
traits of board members, including the education level and length of tenure, are all correlated with firm performance; therefore, we propose hypothesis 1 :

$\mathrm{H}_{1}$ : Education level and seniority of board members affect the firm's financial performance.

Concerning how board capital influence a firm's innovation and financing decisions, recent studies have discussed from the perspective of the behaviors of board members and top-level managers, i.e. how a firm allocates resource through board members and top-level managers effectively, influencing the strategies of research and development, which further influences performance (Hill and Snell, 1998; Barker and Mueller, 2002; Le et al., 2006; Ren et al., 2012). Relevant studies found that different corporate governance structures (e.g. size, ownership concentration, and top-level manager traits) have influence on R\&D investment, debt ratio, and firm performance (Chen et al., 2004; Dwivedi and Jain, 2005; Wincent et al., 2010; Dalziel et al., 2011). Based on the views above, this studies suggest that there are correlations between the human traits of a firm's directors and R\&D decisions, and financing decisions; therefore, we propose the empirical hypothesis $\mathrm{H}_{2}$ and $\mathrm{H}_{3}$.

$\mathrm{H}_{2}$ : Education level and seniority of board members influence a firm's R\&D decisions.

$\mathrm{H}_{3}$ : Education level and seniority of board members influence the firm's financing decisions.

In which, innovation can bring competitive benefits, increasing future growth for the firm (Calantone et al., 2006). Increasing R\&D expenditure has positive effects on stock price for a firm. In addition, there might be a nonlinear or inverted U-shaped relationship between R\&D inputs and a firm's financial performance (Huang and Liu, 2005; Wang, 2011; Kwon, 2014; Saad and Zantout, 2014; Kuo et al., 2018), indicating that there might be an optimal interval for R\&D intensity. Based on the views, we propose the additional empirical hypothesis $\mathrm{H}_{2-1}$ to observe the link between R\&D decisions and a firm's financial performance.

$\mathrm{H}_{2-1}$ : R\&D intensity influences the firm's financial performance.

Agency theory points out that increase in debt level leads to reduce the agency costs of professional managers and stock supervisors, and results into addness in firm value. Morck et al. (1988), Dwivedi and Jain (2005) both suggested that increase in debt level enhances the influence from external monitors on the firm, reduces the agency problem of the firm, and increases the effectiveness of corporate governance mechanism, which further reflects on the firm's financial performance. On the contrary, Huang et al. (2016) concluded that CEOs tend to oversaturation of debt for business due to overconfidence. Based on the above views, this paper studies whether a firm's financing decisions is correlated to the firm's financing performance, and proposes the additional empirical hypothesis $\mathrm{H}_{3-1}$.

$\mathrm{H}_{3-1}$ : Debt ratio influences the firm's financial performance.

\section{Model Building}

Many studies (Morck et al., 1988; Chen et al., 2004; Dwivedi and Jain, 2005; Wincent et al., 2010; Dalziel et al., 2011) suggest that Tobin's Q takes into consideration the time value of future development of the firm and can be an important indicator of business operation. 
Tobin's Q is the ratio of a firm's market value to its asset replacement cost. The value on the numerator is the market price of the firm on the financial market. The asset replacement cost on the denominator is the basic value of the firm. Since it is not easy to obtain the data on the asset replacement value, in empirical analysis the cost is often substituted by book value, this study modifies the equation as alternative Tobin's Q*.

$$
\text { Alt Tobin's } \mathrm{Q}^{*} \sim \frac{N \times p}{T A}+\frac{M V(T D)}{T A}
$$

In terms of growth capability, a firm can maintain its external competitiveness through enhancing R\&D inputs (Brenner and Rushton, 1989); innovation can bring competitive benefits for the enterprise and increase future growth (Calantone et al., 2006). Sougiannis (1994) and Kothari and Zimmerman (1995) examine the relationship between R\&D expenditure and stock price, and find that announcing increase in $R \& D$ expenditure has positive effects on the firm's stock price, which means that R\&D activity helps to create future earnings and cash flow for the firm. Basing on the model of Patterson (1998) and Schimke and Brenner (2014), this study adopted that R\&D intensity is related to firm price, assuming a linear relationship between them, the multiplier effect is $h_{2}$, and when there are no R\&D inputs on the firm's book, there is still values of $h_{1}$. The linear relationship between $\mathrm{R} \& \mathrm{D}$ intensity and firm price is designed as follows:

$$
p=h_{1}+h_{2} \times(R \& D)+O
$$

In equation (2), $p$ is stock price, $R \& D$ is $R \& D$ intensity $=R \& D$ inputs/ net sales; $h_{1}$ is intercept; $h_{2}$ is regression coefficient, $O$ is the error term.

In addition, based on the suggestion of Sweeney et al. (1997) that a firm's liability market value is highly correlated to total debt. This study assumes that a firm with higher liability book value will have higher total liability market value, with multiplier effect $k$. The relationship between the both is as follows:

$$
M V(T D)=k \times T D
$$

In equation (3), $T D$ is total debt; $k$ is multiplier. Substitute equation (2) and (3) into (1):

Alt Tobin's $\mathrm{Q}^{*} \sim \frac{N \times p}{T A}+\frac{k \times T D}{T A}$

$$
\begin{gathered}
\sim \frac{N}{T A} \times\left(h_{1}+h_{2} \times R \& D+O\right)+k \times(D R) \\
\sim \alpha_{0}+\alpha_{1}(R \& D)+\alpha_{2}(D R)+\alpha_{3} O
\end{gathered}
$$

In equation (4), $R \& D$ is $R \& D$ intensity; $D R$ is debt ratio=TD/TA; $\alpha_{0}$ is intercept; $\alpha_{1} \sim \alpha_{3}$ are regression coefficients of this model.

This study integrates the influencing coefficients of related variables into the intercept and regression coefficients of the financial performance model to form equation (4). Based on the model above, we can observe that a firm's performance is essentially represented by a firm's 
market value, and that market value can be classified into equity market value and liability market value. Equity market value is determined by the growth capability of the firm, while liability market value reflects the firm's debt structure. This means that the effects of a firm's R\&D inputs and financing decisions are essentially reflected on the firm's performance.

According to the definition of mediators in Baron and Kenny (1986) and Helm and Mark (2012), this study treats R\&D intensity and financial leverage level as the mediators on financial performance for board capitals. The board capital is defined as the board's ability to provide resources to the firm (Hillman and Dalziel, 2003). For the purpose of measuring, the education level and tenure length of Board members are treated as the rough proxies of board capitals, to observe how they further influence the firm's financial performance through R\&D activity and financing decisions.

In the empirical analysis structure constructed according to the analytic procedure for mediator variables (see figure 1), this study discusses the relationship between the board capital and firm performance, and introduces $R \& D$ intensity and financial leverage level as mediatory variables, to test if the five hypotheses $\left(\mathrm{H}_{1}, \mathrm{H}_{2}, \mathrm{H}_{2-1}, \mathrm{H}_{3}\right.$, and $\left.\mathrm{H}_{3-1}\right)$ are significant. If the five hypotheses are significant after test, they confirm that education level and tenure length of the Board members influence the financial performance through important internal decisions (e.g. R\&D input and financial leverage level).

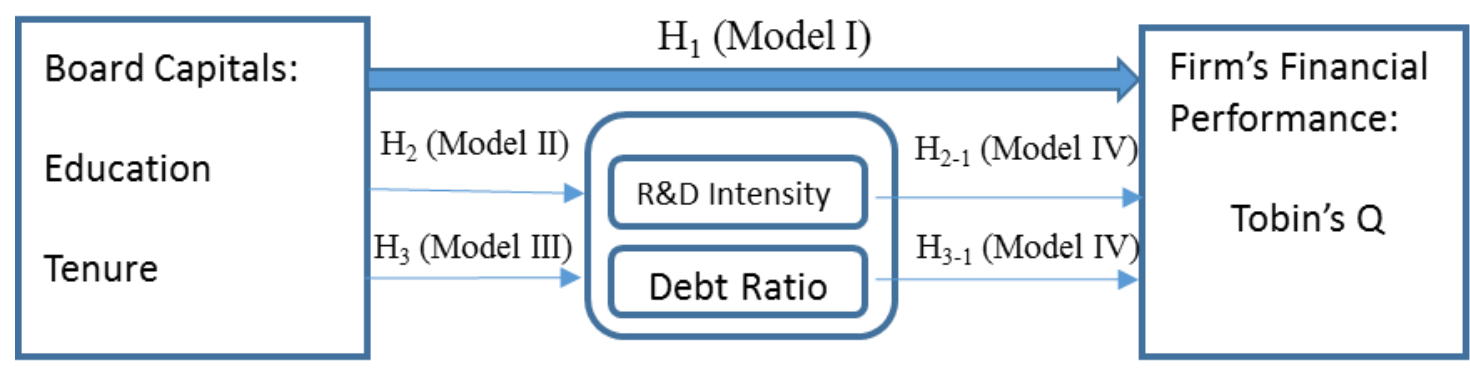

Figure 1. The empirical mediator structure in Board Capitals Model

Figure 1 shows that the education level and seniority of board members, in terms of direct effects, can influence a firm's financial performance. In terms of mediational effects, the education level and seniority of board members can influence important mediators (R\&D intensity and debt ratio), then further reflect on the firm's performance.

According to the mediational procedure of Baron and Kenny (1986), the model for the influences on financial performance (Model I), R\&D intensity (Model II) and debt ratio (Model III) of board capitals are all set up as equation (5):

$$
\begin{aligned}
& \text { Tobin's } Q_{i t}\left(\text { or } R \& D_{i t} \text { or } \mathrm{DR}_{i t}\right)=\beta_{0}+\beta_{1} \text { Chairedu }_{i t}+\beta_{2} \text { Chairtenure }_{i t}+
\end{aligned}
$$

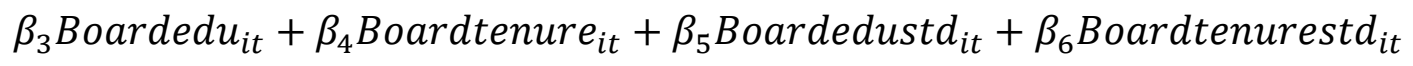

$$
\begin{aligned}
& +\mu_{i}+\varepsilon_{i t}
\end{aligned}
$$


$i=1,2, \ldots$, n company

$t=1,2, \ldots$, T period

$\mu_{i}$ : The error term of intercept $\sim \operatorname{iid}\left(0, \sigma_{u}^{2}\right)$

$\varepsilon_{i t}$ : The error term of the whole model $\sim \operatorname{iid}\left(0, \sigma_{\varepsilon}^{2}\right)$

The proxy variable for firm performance (Tobin's $Q$ ) is Tobin's $Q^{*}$; the proxy variable for research and development decisions is $\mathrm{R} \& \mathrm{D}$ intensity (abbreviated as $R \& D$ ); the proxy variable for financing decisions is Debt Ratio (abbreviated as $D R$ ).

In addition, the human trait variables of the board capitals are collected as the education level and tenure of the chairperson, the mean of the education and tenure of all board members, and the standard deviation of the education and tenure length of the board members. In which, the proxy variables for the education level of the chairperson and board members (Chairedu and Boardedu in equation (5)) are the year's length of education for the members (elementary $=6$ years, middle school $=12$ years, bachelor $=16$ years, master $=18$ years, doctor degree $=22$ years). The lengths of tenure for the chairperson and board members (Chairtenure and Boardtenure in equation (5)) are the proxy variables for adaptive culmination of expertise (Kor and Sundamuthy, 2009; Brookman and Thistle, 2009). Based on the suggestion of Mashdeo et al. (2012) that board diversity has significant correlation with firm performance, we use the standard deviation of the number of years in education for board members (Boardedustd in equation (5)) as the proxy variable for education diversification of the board, and the standard deviation of the number of years in tenure (Boardtenurestd in equation (5)) as the proxy variable for diversified adaptive expertise for board members.

Based on equation (4), this study constructs the empirical model of R\&D intensity and financial leverage on firm performance (Model IV) as follows:

$$
\operatorname{Tobin}_{i t}=\alpha_{0}+\alpha_{1} R \& D_{i t}+\alpha_{2} D R_{i t}+\mu_{i}+\varepsilon_{i t}
$$

In equation (5) and (6), Model I IV test respectively $\mathrm{H}_{1}$ (education and tenure of board members influence a firm's financial performance), $\mathrm{H}_{2}$ (education and tenure of board members influence $\mathrm{R} \& \mathrm{D}$ decisions), and $\mathrm{H}_{3}$ (education and tenure of board members influence a firm's financing decisions). Model IV(i.e. equation(6)) tests $\mathrm{H}_{2-1}$ (R\&D intensity influences a firm's performance), and $\mathrm{H}_{3-1}$ (debt ratio influences a firm's performance). If all of the hypotheses are significantly confirmed, they indicate that education and tenure of board members can significantly influence a firm's performance through the two mediators of R\&D decisions and financing decisions (See Baron and Kenny, 1986).

In order to observe the mediational effects of $R \& D$ intensity and financial leverage; the empirical model (Model V) is designed as follows:

$$
\begin{gathered}
\text { Tobin }_{i t}=\gamma_{0}+\gamma_{1} \text { Chaired }_{i t}+\gamma_{2} \text { Chairtenure }_{i t}+\gamma_{3} \text { Boarded }_{i t} \\
+\gamma_{4} \text { Boardtenure }_{i t}+\gamma_{5} \text { Boardedustd }_{i t}+\gamma_{6} \text { Boardtenurestd }_{i t} \\
+\gamma_{7} R \& D_{i t}+\gamma_{8} \text { DR }_{i t}+\mu_{i}+\varepsilon_{i t}
\end{gathered}
$$


Basing to the definition of mediator by Baron and Kenny (1986) and Holmbeck (2002), The difference, $\left(\beta_{i}-\gamma_{i}\right)$, of the regression coefficients for the same explanatory variables in the two models of equation (5) and (7), indicates the mediational influence of the explained variable after the introduction of mediators. Accordingly, this study adopts the degree of the difference for regression coefficients $\left(\left(\beta_{i}-\gamma_{i}\right) / \gamma_{i}\right)$ as the mediational effect, and the rest of the influencing effects $\left(1-\left(\beta_{i}-\gamma_{i}\right) / \gamma_{i}\right)$ as the direct effect of board capital variables on the firm's financial performance.

Kuo et al. (2018) empirically find that high education level for CEO and board ofd directors help to increase firm value, and that with the increase of CEO tenure length, the difference between the education level of the CEO and of board members on firm value gradually increases. In addition, smaller difference is beneficial to the creation of value for small sized or new firms, while bigger difference is beneficial for large or mature firms. Therefore, this study further takes into consideration if the education level of the chairperson of the board is higher than the mean of the education level of the board members (i.e. if the chairperson has the trait of education leader), and if the tenure length of the board chairperson is greater than the tenure length of the board members (i.e. if the chairperson has the trait of tenure leader), to analyze the influence of the education and tenure of board chairperson on the firm's financial performance, the empirical model is as follows:

$$
\begin{aligned}
\text { Tobin }_{i t}= & \delta_{0}+\delta_{1} \text { Chairedu }_{i t}+\delta_{2} \text { Edulead }_{i t}+\delta_{3} \text { Chairtenure }_{i t}+ \\
& \delta_{4} \text { Tenurelead }_{i t}+\delta_{5} R \& D_{i t}+\delta_{6} D R_{i t}+\mu_{t}+\varepsilon_{i t}
\end{aligned}
$$

In equation (8), Edulead is the education leader trait for board chairperson, measured by the difference between the number of years in education for board chairperson and the mean of the number of years in education for board members; Tenurelead is the tenure leader trait for board chairperson, measured by the difference between the tenure length of board chairperson and board members. In addition, this study takes into consideration that the board size might also be a factor to firm operation (Cristina, 2013) and, in order to exclude the influence from scale, this study adds the number of board seats as the control variable.

Since the empirical data for this study is panel data, it includes samples in cross-sectional and time-series data format; Hsiao $(2003,2005)$ suggests that panel data analysis can decrease the problem of collinearity between variables, contains more degree of freedom to effectively measure those effects that cannot be tested purely by cross-sectional or time-series data, and is more capable of testing individual effects and intertemporal dynamic effects. Therefore, this study adopts panel data analysis for empirical analysis. However, panel data analysis can be classified into fixed effect model and random effect model. Fixed effect model uses fixed intercept to represent different structures in the model; this model assumes that the heterogeneity comes from the population itself, the similarity is low in the population, and use the whole population to observe the difference between each sample. Random effect model uses random intercept to represent different regression model; there are no correlation between intercept and explanatory variable; the random effect model emphasizes on the relationship of the population as a whole, instead of the difference between individual samples. The evaluation standard for the two models is "if there are correlation between 
intercept and independent variable". When Hausman-test result is insignificant, it indicates that intercept is unrelated to explanatory variable and random effect model should be used for estimation. When Hausman-test result is significant, it indicates that intercept is related to explanatory variable and fixed effect model should be used for estimation.

In addition, the regression analysis of the influencing factors to firm performance can, due to the correlation between independent variable and error term, result into endogeneity (independent variable and error term cause each other). To avoid endogeneity, which results into inconsistent estimate for the regression model, this study adopts IV-2SLS (Instrumental Variables and Two Stage Least Square Method) model (Baun et al., 2003; Lee et al., 2016), and use Hausman's endogeneity test to see if there are endogeneity in the empirical data. If there are endogeneity issues, we use lag-1 independent variable as instrumental variable. The

first stage estimates the dependent variable from Model $\mathrm{I} \sim \mathrm{V}$ (e.g. T $\widehat{\operatorname{obln}} Q, \widehat{R \& D}, \widehat{D R}$ ).

The second stage estimates the regression coefficient through the estimate of dependent variables with LS method. The two stages estimation method can correct the inconsistency of estimation from endogeneity.

Due to insignificance with Hausman-test for Model $\mathrm{I} \sim \mathrm{V}$ in our study, the intra-model intercepts and explanatory variables are not correlated, and random effect model should be used for all estimations. In addition, the plus-minus signs for the regression coefficient from the two estimations (LS and IV-2SLS) are the same. We can conclude that the endogeneity is not serious and does not impact the plus-minus direction of the theorem. Taking into consideration of endogeneity issues, this study discloses the results from IV-2SLS model estimation in Section 4.

\section{Descriptive Statistics}

This study takes the listed firms from Mainland China and Taiwan as the study samples, the data collected include listed firms from Shanghai and Shenzhen Stock Exchange (of China), listed firms from Taiwan Stock Exchanges and Taipei Stock Exchanges (of Taiwan). Listed firms from these stock exchanges are representative of firms from across the Taiwan strait and share the business culture of the Sinosphere. Since the both histories for development of corporate governance across the strait are similar, it is sufficient to form a basis for comparative analysis.

Therefore, this study collects listed firms from the four exchanges mentioned above from 2012 to 2017. Among which, there are about 1,500 listed firms in Taiwan, with a total of 8,414 completely recorded data observations from the 6 years (samples with incomplete data on R\&D inputs and board information are deleted). There are about 2,500 firms in Mainland China, with a total of 12,845 completely recorded observations from the 6 years. The contents of the data include financial statement, prospectus, and filing data by board of directors. The data source is primary Taiwan Economics Journal Database; after reorganizing the data, annual data is used for empirical analysis.

Tobin's Q represents the multiplier of a firm's market value to its replacement cost. Tobin's Q 
of market-based measure is used as the proxy variable for financial performance. For the mediator of board of director traits on the firm's financial performance, this study uses R\&D intensity ( $=\mathrm{R} \& \mathrm{D}$ inputs/net sales) as the operational variable for the research and development input of a firm, and debt ratio (= total debts/ total assets) as the operational variable of degree of the firm's financing. For the board of director traits, this study use number of years in education for board chairperson, number of years in tenure for board chairperson, the mean of the number of years in education for board members, and the mean of the number of years in tenure for board members as the explanatory variables of this study.

Table 1 shows that the financial and board of directors' traits in the listed companies across the straits differ greatly. In terms of financial traits, the mean of the Tobin's Q for listed firms in the region of Mainland China is 3.0365, which is evidently higher than the mean of the Tobin's Q for listed firms in the region of Taiwan (1.2400), indicating that investors in the region of China are more affirmative. On the other hand, $R \& D$ intensity $(=R \& D$ costs/net sales $=6.004 \%$ ) for firms in the region of Taiwan is higher than R\&D intensity of firms in the region of China (4.2656\%). In terms of debt ratio, the performance of the firms from across the strait are very close.

On the other aspect of board capitals, the number of years in education on both regions for board chairperson is close, with around 16 to 18 years (16 for college graduates, 18 for masters). However, in Taiwan, the education level of board chairperson is slightly lower than the mean of the board members, while in China, the education level of the chairperson is slight higher than the mean of the board members. The reason for this difference might be that in Taiwan chairpersons tend to be from the capital providers, with specialists as board members, so that the mean of the education level of board members is higher than that of the chairperson; while, in Mainland China, listed firms tend to be formerly state-owned organizations, chairpersons and board members tend to be assigned by the government, their education levels are one of the considerations for assignments, therefore the education level of the chairperson is higher than that of the mean of board members.

On the other hand, the tenure length for chairpersons in Taiwan is evidently higher than that of Mainland China (17.0853 years for Taiwan, 4.3714 years for Mainland China). The reason should be that the listing of companies has been established in Taiwan for more than 50 years, while listed firms in Mainland China tend to come from state-owned organizations that has been reformed into listed firms in the last decade; since the history of listing is shorter, the chairpersons have shorter tenure length. The situation is the same for the mean of the tenure length of board members, which is evidently higher in Taiwan than in China (13.8537 years for Taiwan, and 3.5803 years for Mainland China). In addition, in terms of the number of seats, the average number of board of director seats (including independent directors) is 18.6456 in Mainland China and 9.4431 seats in Taiwan, which shows that the number of board members for listed firms in Mainland China is evidently higher than that of Taiwan.

To test and avoid collinearity between the explanatory variables, this study performs Pearson correlation coefficient test on the explanatory variables; the test results are organized on Table 2. The Pearson correlation coefficient test results show that, for R\&D intensity and debt 


\section{Al Macrothink}

Business and Economic Research ISSN 2162-4860 2021, Vol. 11, No. 2

ratio, there are significant correlation with performance index (for both Mainland China and Taiwan). However, the correlation between R\&D intensity and debt ratio is only $-0.1879 \sim$ +0.3443 , which is a weak correlation. The relationships between board of director traits (education of chairperson, tenure of chairperson, education of board members, tenure of board members, number of board seats) and Tobin's Q, R\&D intensity or debt ratio also present significant correlations; but the correlations are $-0.1145 \sim+0.0834$, which are weak correlations. However, the tenure length of board of directors and the tenure length of board chairpersons for both Taiwan and Mainland China (0.7943 for Mainland China and 0.6000 for Taiwan) present a medium correlation. To avoid collinearity for the subsequent empirical analysis, this study changes to the tenure lead between chairperson tenure and board member tenure $(=$ the number of years of the tenure of the chairperson - the mean of the number of years of board of director members in tenure) as the proxy variable in the model estimation. In addition, this study also uses the standard deviation for the number of years in education for board members and the standard deviation for the number of years in tenure for board members to represent the education diversity and tenure difference for the board of directors.

Table 1. Descriptive Statistics of Sample Characteristics for Taiwan and Mainland China

\begin{tabular}{|c|c|c|c|c|c|c|c|c|c|c|c|c|}
\hline Taiwan & $\begin{array}{l}\text { Tobin's } \\
\text { Q }\end{array}$ & $\begin{array}{l}\text { R\&D } \\
\text { Intensity } \\
(\%)\end{array}$ & $\begin{array}{l}\text { Debt } \\
\text { Ratio } \\
(\%)\end{array}$ & $\begin{array}{l}\text { Chair } \\
\text { Edu } \\
\text { (years) }\end{array}$ & $\begin{array}{l}\text { Board } \\
\text { Edu } \\
\text { (years) }\end{array}$ & $\begin{array}{l}\text { Edu } \\
\text { Lead } \\
\text { (years) }\end{array}$ & $\begin{array}{l}\text { Board } \\
\text { Edu } \\
\text { Std. } \\
\text { (years) } \\
\end{array}$ & $\begin{array}{l}\text { Chair } \\
\text { Tenure } \\
\text { (years) }\end{array}$ & $\begin{array}{l}\text { Board } \\
\text { Tenure } \\
\text { (years) }\end{array}$ & $\begin{array}{l}\text { Tenure } \\
\text { Lead } \\
\text { (years) }\end{array}$ & $\begin{array}{l}\text { Board } \\
\text { Tenure } \\
\text { Std. } \\
\text { (years) } \\
\end{array}$ & $\begin{array}{l}\text { Board } \\
\text { Seats }\end{array}$ \\
\hline Mean & 1.2400 & 6.0044 & 41.6777 & 17.0157 & 17.1666 & -0.1508 & 4.6058 & 17.0853 & 13.8537 & 3.2316 & 8.6094 & 9.4431 \\
\hline Median & 0.9300 & 1.5409 & 40.9356 & 16.0000 & 17.0000 & -0.4444 & 2.2361 & 16.1225 & 13.5740 & 2.4553 & 7.7740 & 9.0000 \\
\hline Max. & 93.4400 & 929.9517 & 99.7600 & 22.0000 & 21.5556 & 5.7333 & 32.2876 & 64.2500 & 48.0300 & 39.5238 & 46.4362 & 55.0000 \\
\hline Min. & 0.0200 & 0.0000 & 0.6104 & 12.0000 & 12.0000 & -6.5714 & 0.0000 & 0.0000 & 0.0000 & -44.7000 & 0.0000 & 3.0000 \\
\hline Std. Dev. & 1.5147 & 32.6939 & 19.1462 & 1.9673 & 0.9828 & 1.7045 & 5.4865 & 10.8143 & 6.8068 & 8.6572 & 5.2657 & 2.8415 \\
\hline $\begin{array}{l}\text { \# of } \\
\text { Samples }\end{array}$ & 8414 & 8414 & 8414 & 8414 & 8414 & 8414 & 8414 & 8414 & 8414 & 8414 & 8414 & 8414 \\
\hline $\begin{array}{l}\text { Mainland } \\
\text { China }\end{array}$ & $\begin{array}{l}\text { Tobin's } \\
\text { Q }\end{array}$ & $\begin{array}{l}\text { R\&D } \\
\text { Intensity } \\
(\%)\end{array}$ & $\begin{array}{l}\text { Debt } \\
\text { Ratio } \\
(\%)\end{array}$ & $\begin{array}{l}\text { Chair } \\
\text { Edu } \\
\text { (years) }\end{array}$ & $\begin{array}{l}\text { Board } \\
\text { Edu } \\
\text { (years) }\end{array}$ & $\begin{array}{l}\text { Edu } \\
\text { Lead } \\
\text { (years) }\end{array}$ & $\begin{array}{l}\text { Board } \\
\text { Edu } \\
\text { Std. } \\
\text { (years) }\end{array}$ & $\begin{array}{l}\text { Chair } \\
\text { Tenure } \\
\text { (years) }\end{array}$ & $\begin{array}{l}\text { Board } \\
\text { Tenure } \\
\text { (years) }\end{array}$ & $\begin{array}{l}\text { Tenure } \\
\text { Lead } \\
\text { (years) }\end{array}$ & $\begin{array}{l}\text { Board } \\
\text { Tenure } \\
\text { Std. } \\
\text { (years) }\end{array}$ & $\begin{array}{l}\text { Board } \\
\text { Seats }\end{array}$ \\
\hline Mean & 3.0365 & 4.2656 & 42.2097 & 16.8307 & 16.5489 & 0.2818 & 1.1664 & 4.3717 & 3.5803 & 0.7913 & 1.3029 & 18.6456 \\
\hline Median & 2.2359 & 3.2595 & 40.5500 & 16.0000 & 16.4118 & 0.0000 & 0.8958 & 3.0014 & 2.9858 & 0.1459 & 0.7583 & 18.0000 \\
\hline Max. & 349.0635 & 288.1697 & 861.1800 & 22.0000 & 19.6471 & 11.0435 & 21.5099 & 29.2274 & 12.1909 & 23.8573 & 17.2286 & 63.0000 \\
\hline Min. & 0.0530 & 0.0000 & 0.8000 & 4.0000 & 4.9565 & -13.3636 & 0.0000 & 0.0027 & 0.3872 & -7.4214 & 0.0000 & 5.0000 \\
\hline Std. Dev. & 4.2196 & 6.0873 & 22.7376 & 1.8127 & 0.5625 & 1.7601 & 1.4118 & 3.3953 & 1.4689 & 2.4101 & 1.2611 & 5.0698 \\
\hline $\begin{array}{l}\text { \# of } \\
\text { Samples }\end{array}$ & 12845 & 12845 & 12845 & 12845 & 12845 & 12845 & 12845 & 12845 & 12845 & 12845 & 12845 & 12845 \\
\hline
\end{tabular}


Table 2. Correlation Coefficient Test for Samples from Taiwan and Mainland China

\begin{tabular}{|c|c|c|c|c|c|c|c|c|c|c|}
\hline Taiwan & $\begin{array}{l}\text { Tobin's } \\
\text { Q }\end{array}$ & $\begin{array}{l}\text { R\&D } \\
\text { Intensity } \\
(\%)\end{array}$ & $\begin{array}{l}\text { Debt } \\
\text { Ratio (\%) }\end{array}$ & $\begin{array}{l}\text { Chair } \\
\text { Edu (year) }\end{array}$ & $\begin{array}{l}\text { Board } \\
\text { Edu (year) }\end{array}$ & $\begin{array}{l}\text { Board Edu } \\
\text { Std. (year) }\end{array}$ & $\begin{array}{l}\text { Chair } \\
\text { Tenure } \\
\text { (year) }\end{array}$ & $\begin{array}{l}\text { Board } \\
\text { Tenure } \\
\text { (year) }\end{array}$ & $\begin{array}{l}\text { Board } \\
\text { Tenure } \\
\text { Std. (year) }\end{array}$ & $\begin{array}{l}\text { Board } \\
\text { Seats }\end{array}$ \\
\hline Tobin's Q & 1.0000 & & & & & & & & & \\
\hline $\begin{array}{l}\mathrm{R} \& \mathrm{D} \\
\text { Intensity } \\
(\%)\end{array}$ & $0.3443 * * *$ & 1.0000 & & & & & & & & \\
\hline $\begin{array}{l}\text { Debt Ratio } \\
(\%)\end{array}$ & $-0.1879 * * *$ & $-0.1577 * * *$ & 1.0000 & & & & & & & \\
\hline Chair Edu & $0.0618 * * *$ & $0.0993 * * *$ & -0.0045 & 1.0000 & & & & & & \\
\hline Board Edu & $0.0834 * * *$ & $0.0807 * * *$ & -0.0115 & 0.4993 *** & 1.0000 & & & & & \\
\hline $\begin{array}{l}\text { Board Edu } \\
\text { Std. }\end{array}$ & 0.0205 & 0.0078 & $0.0232 *$ & $0.0749 * * *$ & $0.1476^{* * *}$ & 1.0000 & & & & \\
\hline $\begin{array}{l}\text { Chair } \\
\text { Tenure }\end{array}$ & $-0.0800 * * *$ & $-0.0511 * * *$ & $0.01728 * * *$ & $-0.0775^{* * *}$ & $-0.0770 * * *$ & $-0.0336^{* *}$ & 1.0000 & & & \\
\hline $\begin{array}{l}\text { Board } \\
\text { Tenure }\end{array}$ & $-0.1158 * * *$ & $-0.0586 * * *$ & -0.0100 & $-0.0654 * * *$ & $-0.1575 * * *$ & $-0.2222 * * *$ & $0.6000 * * *$ & 1.0000 & & \\
\hline $\begin{array}{l}\text { Board } \\
\text { Tenure } \\
\text { Std. } \\
\end{array}$ & $-0.0791 * * *$ & $-0.0462 * * *$ & $-0.0054 * * *$ & $-0.0501 * * *$ & $-0.1229 * * *$ & $0.0111^{* * * *}$ & $0.4033 * * *$ & $0.7406^{* * *}$ & 1.0000 & \\
\hline $\begin{array}{l}\text { Board } \\
\text { Seats }\end{array}$ & 0.0154 & -0.0014 & $0.0669 * * *$ & $0.0473 * * *$ & -0.0029 & $-0.0800 * * *$ & 0.0119 & $0.0229 *$ & $-0.0679 * * *$ & 1.0000 \\
\hline $\begin{array}{l}\text { Mainland } \\
\text { China }\end{array}$ & $\begin{array}{l}\text { Tobin's } \\
\text { Q }\end{array}$ & $\begin{array}{l}\text { R\&D } \\
\text { Intensity } \\
(\%) \\
\end{array}$ & $\begin{array}{l}\text { Debt } \\
\text { Ratio (\%) }\end{array}$ & $\begin{array}{l}\text { Chair } \\
\text { Edu (year) }\end{array}$ & $\begin{array}{l}\text { Board } \\
\text { Edu (year) }\end{array}$ & $\begin{array}{l}\text { Board Edu } \\
\text { Std. (year) }\end{array}$ & $\begin{array}{l}\text { Chair } \\
\text { Tenure } \\
\text { (year) } \\
\end{array}$ & $\begin{array}{l}\text { Board } \\
\text { Tenure } \\
\text { (year) } \\
\end{array}$ & $\begin{array}{l}\text { Board } \\
\text { Tenure } \\
\text { Std. (year) }\end{array}$ & $\begin{array}{l}\text { Board } \\
\text { Seats }\end{array}$ \\
\hline Tobin's Q & 1.0000 & & & & & & & & & \\
\hline $\begin{array}{l}\mathrm{R} \& \mathrm{D} \\
\text { Intensity } \\
(\%)\end{array}$ & $0.1297 * * *$ & 1.0000 & & & & & & & & \\
\hline $\begin{array}{l}\text { Debt Ratio } \\
(\%)\end{array}$ & $-0.1679 * * *$ & $-0.2510 * * *$ & 1.0000 & & & & & & & \\
\hline Chair Edu & $-0.0347 * * *$ & $0.0261 * * *$ & 0.0147 & 1.0000 & & & & & & \\
\hline Board Edu & -0.0073 & $0.0627 * * *$ & $0.0255^{* *}$ & 0.2521 *** & 1.0000 & & & & & \\
\hline $\begin{array}{l}\text { Board Edu } \\
\text { Std. }\end{array}$ & $-0.0364 * * *$ & 0.0147 & 0.0082 & $0.1307 * * *$ & $0.4785^{* * *}$ & 1.0000 & & & & \\
\hline $\begin{array}{l}\text { Chair } \\
\text { Tenure }\end{array}$ & $0.0483^{* * *}$ & $0.0932 * * *$ & $-0.1170 * * *$ & $0.0707 * * *$ & $-0.1117 * * *$ & $-0.1132 * * *$ & 1.0000 & & & \\
\hline $\begin{array}{l}\text { Board } \\
\text { Tenure }\end{array}$ & $0.0631 * * *$ & $0.0849 * * *$ & $-0.1252 * * *$ & $0.0359 * * *$ & $-0.1073 * * *$ & $-0.1268 * * *$ & $0.7943 * * *$ & 1.0000 & & \\
\hline $\begin{array}{l}\text { Board } \\
\text { Tenure } \\
\text { Std. } \\
\end{array}$ & $0.0257 * *$ & $0.0537 * * *$ & $-0.0526 * * *$ & $0.0529 * * *$ & $-0.1025 * * *$ & $-0.0384 * * *$ & $0.7113 * * *$ & $0.7342 * * *$ & 1.0000 & \\
\hline $\begin{array}{l}\text { Board } \\
\text { Seats }\end{array}$ & $-0.1145^{* * *}$ & $-0.0879 * * *$ & $0.2609 * * *$ & $0.0466^{* * * *}$ & $0.1253 * * *$ & $0.0829 * * *$ & $-0.1405^{* * * *}$ & $-0.1659 * * *$ & $-0.0600 * * *$ & 1.0000 \\
\hline
\end{tabular}

Note: $*$ at $5 \%$ level of significance, $* *$ at $1 \%$ level of significance, $* * *$ at $0.1 \%$ level of significance

\section{Mediational Effects}

Once the research variables are confirmed, this study proceeds with the empirical robustness analysis for Model I V (see Table 3). The design of Model I is to observe and test if H1 (the education and tenure of Board members influence firm performance) is significant. Model II observes if $\mathrm{H} 2$ (education and tenure of board members influence R\&D decisions of the firm) is confirmed. Model III tests if H3 (education and tenure of board members influence financing decisions of the firm) is significant. Model IV analyzes if H2-1(R\&D decisions influence firm performance) and H3-1(financing decisions influence firm performance) are significant. The difference between Model I and Model V is designed to evaluate the degree of mediational effect from the introduction of mediators. 
In Table 3 for the region of Taiwan, Model I is significant (the model fitness for education model: $\mathrm{F}=12.7609 * * *$; the model fitness for tenure model: $\mathrm{F}=18.6307 * * *)$, this study indicates that the education and tenure of board members have influences on the firm's performance. In the education model, higher the mean of the number of years for board members in education is correlated with higher firm performance. Higher standard deviation for the number of years in education for board numbers (higher educational diversity) might cause lower integration among the board members, and lower firm performance. As for the tenure model, lower tenure length for the board of directors results into better firm performance.

Model II shows that board of directors traits significantly influence the level of R\&D input. In which, higher education level for board chairperson is correlated with more emphasis on research and development. Conversely, the mean of the tenure length for the board members does not have a significant relationship with firm performance. In addition, Model III is significant (model fit for education model, $\mathrm{F}=5.9182 * * *$; model fit for tenure model, $\mathrm{F}=6.5801^{* * *}$ ), indicating that board of directors traits significantly influence the firm's debt ratio (financing decisions). In which, lower education level for board chairperson, and more board seats, increase the debt ratio of the firm.

In terms of Model IV, for Taiwan, increasing R\&D intensity increases a firm's Tobin's Q (proxy variable for financial performance); however, increasing debt ratio decreases significantly firm's financial performance. Because board of directors traits might influence firm performance through R\&D decisions and financing decisions, this study builds Model I (without mediator model) and Model V (with mediator model) to observe the mediational influence of board of directors traits through $\mathrm{R} \& \mathrm{D}$ decisions and financing decisions as mediators. Comparing the Model I and Model V for Taiwan, we can find that mediational effect are about $22.3114 \% \sim 35.6538 \%$, i.e. the degree of influence of education level of board members through R\&D and financing decisions on firm performance is $35.653 \%$. On contract, direct effect can be estimated as $64.3462 \%(1-35.6538 \%=64.3462 \%)$, it means that education level for board members also directly influence firm performance: higher education levels for boards result into higher financial performance, with direct effect of $64.3462 \%$. Additionally, the board diversity in education influence Tobin's Q with $22.3114 \%$ mediational effect, and $77.6886 \%$ direct effect.

On the tenure model, Table 3 also shows that a firm's financial performance is not significantly influenced by the length of tenure for board of directors through mediators in Taiwan, while the direct effect has an absolute ratio. It indicates that the tenure trait of board members almost completely influences a firm's financial performance through direct effects. In which, lower tenure length for board members result into better firm performance. Also, based on the principle of cooperate governance, this study suggests that the tenure length for board of directors should be controlled to avoid negative influence on financial performance (see Table 3, tenure model, board member tenure traits; the regression coefficient is significantly negative).

Table 4 is the analysis for the region of China. Model I is significant (the model fitness for 
education model is $\mathrm{F}=36.1929 * *$; the model fitness for tenure model is $\mathrm{F}=60.9489 * *$ ), the result indicates that education and tenure trait of board members influence a firm's performance. In the education model, higher number of years in education for chairperson and board members result into better firm performance. Higher standard deviation of education for board members (more diverse education for board members) possibly leads to worse integration of the board, results into worse performance for the firm. In terms of tenure model, the tenure trait of board members does not have significant influence on firm performance. This phenomenon might be inferred that most of the listed companies in the region of China come from reformed state-owned enterprises in the last decade; many board members have similar tenure length (the standard deviation for the tenure length of board members is 8.6094 years for Taiwan and 1.3029 years for Mainland China), as a result, the tenure trait of board members in China does not have significant impact on firm performance.

In Table 4 Model II, higher education level for board chairperson is correlated with higher emphasis on research and development. Unlike Taiwan, in Mainland China, firms with higher tenure length for board of directors have higher emphasis on research and development. This phenomenon might be because the tenure length for board members is 13.8537 years in Taiwan, which is much greater than 3.5803 years in Mainland China, indicating that the average tenure length of board members in Taiwan is longer than appropriate tenure length; thus too long tenure lead to cease to influence R\&D decisions significantly; while the average tenure length for board members in Mainland China is shorter than the optimal tenure length; thus longer tenure length has significant influence on important decisions. This phenomenon is also reflected on Model III as significant, indicating that board of directors traits significantly influence a firm's debt ratio (financing decisions). In which, higher education level and shorter tenure for board of directors result into increased debt ratio. In terms of the Model IV for China, increasing R\&D inputs increases a firm's Tobin's Q; however, increasing debt ratio decreases a firm's financial performance.

Observation on Table 4 Model I and Model V finds that higher education level for board chairperson and board members result into better firm performance. The mediational effect is $28.4576 \% \sim 39.4688 \%$, i.e. the degree of influence of education level of board members through $\mathrm{R} \& \mathrm{D}$ and financing decisions on firm performance is $28.4576 \%$. 
Table 3. Estimation of Model I Model V for Taiwan

\begin{tabular}{|c|c|c|c|c|c|c|c|}
\hline \multicolumn{2}{|c|}{ Explained Variables } & \multicolumn{6}{|l|}{ Taiwan } \\
\hline & & $\begin{array}{l}\text { Model I } \\
\text { Tobin's Q }\end{array}$ & $\begin{array}{l}\text { Model II } \\
\text { R\&D Intensity }\end{array}$ & $\begin{array}{l}\text { Model III } \\
\text { Debt Ratio }\end{array}$ & $\begin{array}{l}\text { Model IV } \\
\text { Tobin's Q }\end{array}$ & $\begin{array}{l}\text { Model V } \\
\text { Tobin's Q }\end{array}$ & $\begin{array}{l}\text { Mediational } \\
\text { Effect }\end{array}$ \\
\hline \multirow[t]{9}{*}{ Education Model } & Intercept & $-1.4961 * *$ & -27.0095 & 8.1480 & $1.7799 * * *$ & -0.504212 & $66.2996 \%$ \\
\hline & Chair Education & 0.0255 & $3.2219 * * *$ & $-3.6754 * * *$ & & $-0.0695^{*}$ & ----- \\
\hline & Board Education & $0.1430 * * *$ & -1.3965 & $4.6271^{*}$ & & $0.1940 * * *$ & $35.6538 \%$ \\
\hline & $\begin{array}{l}\text { Board } \\
\text { Education Std. }\end{array}$ & $-0.0275^{* *}$ & 1.0237 & 0.3193 & & $-0.0336 * * *$ & $22.3114 \%$ \\
\hline & Board Seats & -0.0030 & -0.2311 & $1.6109^{*}$ & & 0.0179 & $\begin{array}{ll}---- \\
\end{array}$ \\
\hline & R\&D Intensity & & & & $0.0105^{* * * *}$ & $0.0212 * * *$ & \\
\hline & Debt Ratio & & & & $-0.0144 * * *$ & $-0.0128 * * *$ & \\
\hline & Hausman Test & 0.0000 & 0.0000 & 0.0000 & 0.0000 & 0.0000 & \\
\hline & Model Fit (F-test) & $12.7609 * * *$ & $13.1749 * * *$ & $5.9182 * * *$ & $68.6945 * * *$ & 42.0534 & \\
\hline \multirow{9}{*}{ Tenure Model } & Intercept & $1.4824 * * *$ & $10.0260 * * *$ & $34.4025^{* * *}$ & $1.7799 * * *$ & $1.5520 * * *$ & $3.0853 \%$ \\
\hline & Chair Tenure & -0.0034 & -0.0061 & 0.0005 & & -0.0392 & $-\cdots$ \\
\hline & Board Tenure & $-0.0218 *$ & -0.1161 & 0.0608 & & 0.0232 & ----- \\
\hline & Board Tenure Std. & 0.0059 & -0.2577 & -0.1118 & & 0.0075 & ----- \\
\hline & Board Seats & 0.0061 & -0.0509 & $0.7646^{* * * *}$ & & 0.0487 & ----- \\
\hline & R\&D Intensity & & & & $0.0105 * * *$ & $0.0127 * * *$ & \\
\hline & Debt Ratio & & & & $-0.0144 * * *$ & $-0.0125 * * *$ & \\
\hline & Hausman Test & 0.0000 & 0.0000 & 0.0000 & 0.0000 & 0.0000 & \\
\hline & Model Fit (F-test) & $18.6307 * * *$ & $4.4796 * * *$ & $6.5801 * * *$ & $68.6945^{* * * *}$ & $30.6575^{* * *}$ & \\
\hline
\end{tabular}

Note: $1 . *$ at $5 \%$ level of significance, $* *$ at $1 \%$ level of significance, $* * *$ at $0.1 \%$ level of significance

2. When Hausman-test result is significant, it indicates that intercept is related to explanatory variable and fixed effect model should be used for estimation.

Table 4. Estimation of Model I Model V for Mainland China

\begin{tabular}{|c|c|c|c|c|c|c|c|}
\hline \multirow{2}{*}{\multicolumn{2}{|c|}{ Explained Variables }} & \multirow{2}{*}{\multicolumn{6}{|c|}{ China }} \\
\hline & & & & & & & \\
\hline & & $\begin{array}{l}\text { Model I } \\
\text { Tobin's Q }\end{array}$ & $\begin{array}{l}\text { Model II } \\
\text { R\&D Intensity }\end{array}$ & $\begin{array}{l}\text { Model III } \\
\text { Debt Ratio }\end{array}$ & $\begin{array}{l}\text { Model IV } \\
\text { Tobin's Q }\end{array}$ & $\begin{array}{l}\text { Model V } \\
\text { Tobin's Q }\end{array}$ & $\begin{array}{l}\text { Mediational } \\
\text { Effects }\end{array}$ \\
\hline \multirow{9}{*}{$\begin{array}{l}\text { Education } \\
\text { Model }\end{array}$} & Intercept & -45.8841 & 53.7611 & $-232.6778 * * *$ & $3.8714 * * *$ & $-59.61774 *$ & ------ \\
\hline & Chair Education & $0.3773 * *$ & $0.9449 *$ & 0.87383 & & $0.2639^{*}$ & $30.0432 \%$ \\
\hline & Board Education & $3.1474 *$ & -4.2854 & $14.6062^{* * *}$ & & $4.0431 *$ & $28.4576 \%$ \\
\hline & $\begin{array}{l}\text { Board } \\
\text { Education Std. }\end{array}$ & $-2.6978^{*}$ & $5.4966^{*}$ & $-16.6131 * *$ & & $-3.7626^{* *}$ & $39.4688 \%$ \\
\hline & Board Seats & $-0.3746^{* * * *}$ & 0.0095 & $1.8500 * * *$ & & $-0.3183 * * *$ & $15.0155 \%$ \\
\hline & R\&D Intensity & & & & $0.1128 * * *$ & $0.1067 * * *$ & \\
\hline & Debt Ratio & & & & $-0.0302 * * *$ & 0.0116 & \\
\hline & Hausman Test & 0.0000 & 0.0000 & 0.0000 & 0.0082 & 0.0000 & \\
\hline & Model Fit (F-test) & $36.1929 * * *$ & $11.8045^{* * * *}$ & $106.3662 * * *$ & $123.2092 * * *$ & $97.7711^{* * * *}$ & \\
\hline \multirow{9}{*}{$\begin{array}{l}\text { Tenure } \\
\text { Model }\end{array}$} & Intercept & $6.1566^{* * * *}$ & -2.1451 & $221.9163^{* * * *}$ & $3.8714 * * *$ & $6.2848 * * *$ & $2.0821 \%$ \\
\hline & Chair Tenure & -0.0038 & $0.2977 * * *$ & $-2.5735 * * *$ & & -0.0583 & $\begin{array}{ll}----- \\
\end{array}$ \\
\hline & Board Tenure & 0.0070 & $1.9807 * * *$ & $-19.6408 * * *$ & & -0.1582 & $\begin{array}{l}----- \\
--1\end{array}$ \\
\hline & Board Tenure Std. & -0.1860 & $-2.8204 * * *$ & $22.7101 * * *$ & & 0.0442 & ----- \\
\hline & Board Seats & $-0.1528 * * *$ & 0.090751 & $-6.8787 * * *$ & & $-0.1181 * * *$ & $22.6720 \%$ \\
\hline & R\&D Intensity & & & & $0.1128 * * *$ & $0.1130 * * *$ & \\
\hline & Debt Ratio & & & & $-0.0302 * * *$ & $-0.0161 * * *$ & \\
\hline & Hausman Test & 0.7423 & 0.0176 & 0.0000 & 0.0082 & 3.6189 & \\
\hline & Model Fit (F-test) & $60.9489 * * *$ & $5.4020 * * *$ & $15.3606 * * *$ & $123.2092^{* * * *}$ & $93.4448 * * *$ & \\
\hline
\end{tabular}

Note: $1 . *$ at $5 \%$ level of significance, $* *$ at $1 \%$ level of significance, $* * *$ at $0.1 \%$ level of significance

2. When Hausman-test result is significant, it indicates that intercept is related to explanatory variable and fixed effect model should be used for estimation.

On contract, direct effect can be estimated as $71.5424 \%(1-28.4576 \%=71.5424 \%)$, it means 
that education level for board members also directly influence firm performance: higher education levels for boards result into higher financial performance. The phenomenon might be caused by the mass reformation of state-owned business into listed firms; board chairpersons tend to be assigned by the government, which uses education level as a referencing for assignment. Higher education level for board of directors means that there are more specialists in the board of directors, which results into better financial performance. Table 4 shows that, in the region of China, higher standard deviation for the number of years in education for board members, and higher number of seats in the board, might hinder the integration of the board of directors, resulting into negative effects on firm performance.

\section{Leadership and Industry Effects}

With the high-tech industry as the core of economic development, research and development has become an important driver of business development. After years of industrial development, technology industry with more than 50\% listed firms became the mainstream in Taiwan. On the other hand, many listed firms in the region of Mainland China are reformed state-owned institutes. Up to 2017, the samples from this study show that the $31.25 \%$ of listed firms belong to technological companies. In general, R\&D activities are the key successful factors in high tech industries.

In addition, chairperson is also the one of important decision makers for firm, with the most capacity to influence corporate decisions, the personal traits of the board chairperson is also expected to significantly influence firm performance. Therefore, this study also observes the personal education and tenure traits of the board chairperson, and adds the consideration if the board chairperson's education level is above the average education level of board members (this variable represents the chairperson has the education leader trait) and if the board chairperson's tenure length is above the average tenure length of board members (this variable represents the chairperson has the tenure leader trait) to influence the firm's financial performance. For the traits of board members, this study also collects four traits (the average education level of board members, the standard deviation for the education level of board members, the average tenure length of board members, and the standard deviation for the tenure length of board members) to observe if the four board traits influence the firm's financial performance.

For the region of Taiwan, as shown on Table 5, the samples are classified into four groups for analysis: technology industry (sample ratio 5774/8414=68.62\%), non-technology industry (sample ratio $31.38 \%$ ). With the estimation of model $\mathrm{I} \sim \mathrm{V}$, Table 5 shows that both education and tenure length significantly influence financial performance: higher education and shorter tenure of chairperson result into better financial performance. The mediational effect is $6.3537 \%$ 46.1927\% in technology Industry. In particular, the more difference between the number of years in education for the chairperson and board members, the more likely it is through R\&D and leverage decisions (mediational effect 21.1502\%), further increases the firm's financial performance. In addition, in the high-tech industry, educational leadership (when the education level of the chairperson is higher than the mean of the education level of the board of directors) is not optimal for the chairperson, with negative regression coefficient 
of $-0.0292 * * *$, indicating that when the chairperson's education level is higher than the average of the board members, it will negatively impact financial performance. The regression coefficient for the mean of the education level of the board is $+0.1390 * *$, which shows that the average level of education of the board of directors is also an important factor to firm operations.

Table 5. Estimation of Chairperson Leadership Traits and Technology Industry

\begin{tabular}{|c|c|c|c|c|c|c|c|c|c|}
\hline \multirow{2}{*}{\multicolumn{2}{|c|}{$\begin{array}{l}\text { Region } \\
\text { Explained } \\
\text { Variables } \\
\end{array}$}} & \multicolumn{4}{|l|}{ Taiwan } & \multicolumn{4}{|l|}{ China } \\
\hline & & \multicolumn{2}{|l|}{$\begin{array}{l}\text { Technology } \\
\text { Industry }\end{array}$} & \multicolumn{2}{|c|}{$\begin{array}{l}\text { Non-technology } \\
\text { industry }\end{array}$} & \multicolumn{2}{|l|}{$\begin{array}{l}\text { Technology } \\
\text { Industry }\end{array}$} & \multicolumn{2}{|c|}{$\begin{array}{l}\text { Non-technology } \\
\text { Industry }\end{array}$} \\
\hline & & $\begin{array}{l}\text { Tobin's } \\
\text { Q } \\
\end{array}$ & $\begin{array}{l}\text { Mediational } \\
\text { Effect }\end{array}$ & $\begin{array}{l}\text { Tobin's } \\
\text { Q }\end{array}$ & $\begin{array}{l}\text { Mediational } \\
\text { Effect }\end{array}$ & $\begin{array}{l}\text { Tobin's } \\
\text { Q } \\
\end{array}$ & $\begin{array}{l}\text { Mediational } \\
\text { Effect }\end{array}$ & $\begin{array}{l}\text { Tobin's } \\
\text { Q } \\
\end{array}$ & $\begin{array}{l}\text { Mediational } \\
\text { Effect }\end{array}$ \\
\hline \multirow{10}{*}{$\begin{array}{l}\text { Chairperson } \\
\text { Traits }\end{array}$} & Intercept & -0.7117 & $\begin{array}{ll}---- \\
--1\end{array}$ & 2.6774 & $\begin{array}{l}---- \\
-\end{array}$ & -16.0558 & $\begin{array}{l}---- \\
--1\end{array}$ & 0.9389 & $\begin{array}{ll}---- \\
--1\end{array}$ \\
\hline & Chair Edu & $0.1395 * * * \prime$ & $46.1927 \%$ & -0.0678 & ------ & $1.7514 * * *$ & $27.6624 \%$ & 0.3789 & ----- \\
\hline & $\begin{array}{l}\text { (Chair Edu- } \\
\text { Board Edu) }\end{array}$ & $-0.1782 * *$ & $21.1502 \%$ & 0.1742 & ----- & $-2.0774 * * *$ & $26.5273 \%$ & $-0.5401^{*}$ & $73.4979 \%$ \\
\hline & Chair Tenure & $-0.0292 * * *$ & $6.3537 \%$ & -0.0045 & ----- & $-0.7893 * *$ & $29.6218 \%$ & $-0.2806^{* *}$ & $8.6440 \%$ \\
\hline & $\begin{array}{l}\text { (Chair Tenure- } \\
\text { Board Tenure) }\end{array}$ & 0.0301 & ----- & -0.0097 & ------ & $0.8429 * *$ & $14.2299 \%$ & 0.2104 & ----- \\
\hline & \# of Seats & 0.0444 & $66.9689 \%$ & 0.0151 & ------ & $-0.3703 * * *$ & $11.1107 \%$ & $-0.1419 * * *$ & $57.9136 \%$ \\
\hline & R\&D Intensity & $0.0115 * * *$ & & $0.1173 *$ & & $0.1299 * * *$ & & $0.0888^{* * *}$ & \\
\hline & Debt Ratio & $-0.0127 * * *$ & & $-0.0118 * * *$ & & 0.0017 & & $-0.0172 * * *$ & \\
\hline & Hausman Test & 0.9907 & & 0.0000 & & 0.0000 & & 0.0000 & \\
\hline & $\begin{array}{l}\text { Model Fit } \\
\text { (F-test) }\end{array}$ & $69.3532 * * *$ & & $11.4016^{* * *}$ & & $20.1603 * * *$ & & 57.7572 & \\
\hline \multirow{10}{*}{$\begin{array}{l}\text { Board } \\
\text { Traits }\end{array}$} & Intercept & -1.2164 & ----- & -1.1983 & ----- & -28.0362 & ----- & 16.6791 & ----- \\
\hline & Board Edu & $0.1390 * *$ & $2.5732 \%$ & 0.2153 & ------ & 2.9957 & ------ & -0.7853 & ----- \\
\hline & $\begin{array}{l}\text { Board Edu } \\
\text { Std. }\end{array}$ & 0.0187 & ------ & -0.4378 & ------ & 1.1620 & ------ & 0.9739 & ------ \\
\hline & Board Tenure & -0.0945 & ------ & -0.3590 & ------ & $-2.4317 * * *$ & $8.7565 \%$ & 0.4106 & ----- \\
\hline & $\begin{array}{l}\text { Board Tenure } \\
\text { Std. }\end{array}$ & 0.1200 & ------ & 0.6627 & ------ & $2.4593 * * *$ & $8.4172 \%$ & -0.7908 & ----- \\
\hline & \# of Seats & $0.0853 * *$ & $24.8191 \%$ & -0.0089 & ------ & $-0.8400 * * *$ & $22.4740 \%$ & -0.0799 & ----- \\
\hline & R\&D Intensity & $0.0103 * * *$ & & $0.0945 * *$ & & $0.1071 * * *$ & & $0.0752 * * *$ & \\
\hline & Debt Ratio & $-0.0120 * * *$ & & $-0.0090 *$ & & $0.0355^{* *}$ & & $-0.0191 * *$ & \\
\hline & Hausman Tests & 0.0000 & & 0.0000 & & 0.0000 & & 0.0000 & \\
\hline & $\begin{array}{l}\text { Model Fit } \\
\text { (F-test) }\end{array}$ & $36.2308 * * *$ & & $13.8754 * * *$ & & $22.0283 * * *$ & & $21.7989 * * *$ & \\
\hline \multicolumn{2}{|l|}{ \# of Samples } & 5774 & & 2640 & & 4014 & & 8831 & \\
\hline
\end{tabular}

Note: $1 . *$ at $5 \%$ level of significance, $* *$ at $1 \%$ level of significance, $* * *$ at $0.1 \%$ level of significance

2. When Hausman-test result is significant, it indicates that intercept is related to explanatory variable and fixed effect model should be used for estimation.

Therefore, we suggest that a chairperson should work with the members of board and make team decisions for R\&D inputs. As for non-technology industry, the education and tenure for board chairperson and board members are all non-significant.

Conversely, the industry structure and the ownership structure of firms in the region of China are different from those of Taiwan. For the influences of industry traits and chairperson traits on financial performance, see Table 5. Firms are classified into technology industry (sample ratio 4014/12845=31.25\%), non-technology industry (sample ratio $68.75 \%$ ). For technology industry, higher education level for chairperson is better for firm performance, while shorter chairperson tenure is better for firm performance, and the average tenure of board members is 
also good for shorter. The relevant mediational effects are $8.4172 \%$ 29.6218\%, which shows that education and tenure traits of the members of the board will influence the firm's financial performance through $\mathrm{R} \& \mathrm{D}$ decisions and financing decisions. The variables with the greatest impact are the education level and tenure length of the chairperson, while the influences from the education level of board is non-significant. For non-technology industry, shorter tenure length for the chairperson results into better financial performance. In addition, it can also be observed form Table 5 that the number of board seats has a relationship with firm performance; large number of seats may cause difficulty to the integration of the board, and may even cause internal differences. Therefore, regardless of tech or non-tech industry, more board seats result into worse performance for firms.

\section{Conclusion}

Board capitals are the sum of the human and social capital of the board of directors. Obviously, board directors give advice and counsel on key areas, such as the formulation of strategies, using their skill and expertise, to help their organizations. For estimating the effectiveness of board capitals, we construct the mediational model to observe the influent paths of board capital on firm performance.

We adopt R\&D intensity and debt ratio as mediators to set up the model, and collect some empirical data to confirm five hypotheses. Through the estimation of regression coefficients, we complete the whole structure, and calculate the direct effect and mediational effect of board capitals on firm performance.

With empirical analysis, our study finds that, for both the region of Mainland China and Taiwan, education and tenure traits of board members influence the firm's performance through the both mediators of $\mathrm{R} \& \mathrm{D}$ decisions and financing decisions. The mediational effect for education level is around $22.3114 \% \sim 35.6538 \%$ in Taiwan, and the mediational effect is around $25.4576 \%$ 39.4688\% in Mainland China. In addition, the education level of board members has higher mediational effect than the tenure level of the board members, which means that it is more significant for the education level of the board members to influence a firm's financial performance through $\mathrm{R} \& \mathrm{D}$ and financing decisions.

This study also observed that, for firms in both Taiwan and Mainland China, higher level of education for the chairperson results into better firm performance, indicating that leadership capital is correlated with firm performance. However, longer tenure length for the board chairperson results into worse firm performance, which also shows that there's a need for rotation mechanism for corporate chairpersons in order to maintain the efficiency of sustainable development. Our study also show that if the board chairperson's tenure exceeds the tenure of the board members, implying that the chairperson is more familiar with the operation of the firm, it results into better financial performance for the firm. In addition, higher standard deviation for the tenure length for the members of boards (indicating a mix of senior and junior members in the board), has significant positive influence on business performance, especially for high-tech industry firms in Mainland China.

For the region of Taiwan, the education level of the chairperson has greater mediational effect. 
By comparing with relevant traits in this study, it can be understood that higher education level for the board chairperson have positive influence on the firm's R\&D intensity, which further increases the firm's overall financial performance (with the proxy variable being Tobin's Q). For the empirical analysis on firms in the region of China, the number of board seats has the greatest negative mediational effect. Since the board of directors of listed firms in China tend to be added the party and union representatives, causing the board to have greater number of seats, the negative effect is quite significant. It is suggested that the number of board seats should be further limited in order to maintain the professionalism of the board members in the operation of the business.

\section{References}

Barker III, V. L., \& Mueller, G. C. (2002). CEO Characteristics and Firm R\&D Spending. Management Science, 48(6), 782-801. https://doi.org/10.1287/mnsc.48.6.782.187

Baron, R. M., \& Kenny, D. A. (1986). The Moderator-Mediator Variable Distinction in Social Psychological Research: Conceptual, Strategic, and Statistical Considerations. Journal of Personality and Social Psychology, 51(6), 1173-1182.

https://doi.org/10.1037/0022-3514.51.6.1173

Baum, C. F., Schaffer, M. E., \& Stillman, S. (2003). Instrumental Variables and GMM: Estimation and Testing. The Stata Journal, 3(1), 1-31.

https://doi.org/10.1177/1536867X0300300101

Brenner, M. S., \& Rushton, B. M. (1989). Sales Growth and R\&D in the Chemical Industry. Research Technology Management, 32(2), 8-15.

https://doi.org/10.1080/08956308.1989.11670580

Brookman, J., \& Thistle, P. D. (2009). CEO Tenure, the Risk of Termination and Firm Value. Journal of Corporate Finance, 5, 331-344. https://doi.org/10.1016/j.jcorpfin.2009.01.002

Calantone, R. J., Chan, K., \& Cui, A. S. (2006). Decomposing Product Innovativeness and Its Effects on New Product Success. Journal of Product Innovation Management, 23(5), 408-421. https://doi.org/10.1111/j.1540-5885.2006.00213.x

Chen, S. S., Ho, K. W., Lee, C. F., \& Shrestha, K. (2004). Nonlinear Models in Corporate Finance Research: Review, Critique, and Extensions. Review of Quantitative Finance and Accounting, 22(2), 141-169. https://doi.org/10.1023/B:REQU.0000015854.90533.be

Dalziel, T., Gentry, R. J., \& Bowerman, M. (2011). An Integrated Agency-Resource Dependence View of the Influence of Directors' Human and Relational Capital on Firms' R\&D Spending. Journal of Management Studies, 48(6), 1217-1242.

https://doi.org/10.1111/j.1467-6486.2010.01003.x

Darmadi, S. (2013). Board Members' Education and Firm Performance: Evidence from a Developing Economy. International Journal of Commerce and Management, 23(2), 113-135. https://doi.org/10.1108/10569211311324911

Dwivedi, N., \& Jain, A. K. (2005). Corporate Governance and Performance of Indian Firms: 
The Effect of Board Size and Ownership. Employee Responsibilities and Rights Journal, 17(3), 161-172. https://doi.org/10.1007/s10672-005-6939-5

Gottesman, A. A., \& Morey, M. R. (2006). Manager Education and Fund Performance. Journal of Empirical Finance, 13(2), 145-182. https://doi.org/10.1016/j.jempfin.2005.10.001

Hausman, J. A. (1978). Specification Tests in Econometrics. Econometrica, 46(6), 1251-1271. https://doi.org/10.2307/1913827

Helm, R., \& Mark, A. (2012). Analysis and Evaluation of Moderator Effects in Regression Models: State of Art, Alternatives and Empirical Example. Review of Managerial Science, 6(4), 307-332. https://doi.org/10.1007/s11846-010-0057-y

Hill, C. W. L., \& Snell, S. A. (1988). External Control, Corporate Strategy, and Firm Performance in Research-Intensive Industries. Strategic management Journal, 9(6), 577-590. https://doi.org/10.1002/smj.4250090605

Hillman, A. J., \& Dalziel, T. (2003). Boards of Directors and Firm Performance: Integrating Agency and Resource Dependence Perspectives. Academy of Management Review, 28(3), 383-396. https://doi.org/10.5465/amr.2003.10196729

Hsiao, C. (2003). Analysis of Panel Data (2nd ed.). Econometric Society Monograph No. 36. Cambridge University Press, New York. https://doi.org/10.1017/CBO9780511754203

Hsiao, C. (2005). Why Panel Data?. Singapore Economic Review, 50(2), 1-12. https://doi.org/10.1142/S0217590805001809

Huang, C. J., \& Liu, C. J. (2005). Exploration for the Relationship between Innovation, IT and Performance. Journal of Intellectual Capital, 6(2), 237-252.

https://doi.org/10.1108/14691930510592825

Huang, R., Tan, K. J. K., \& Faff, R. W. (2016). CEO overconfidence and Corporate Debt Maturity. Journal of Corporate Finance, 36, 93-110.

https://doi.org/10.1016/j.jcorpfin.2015.10.009

Jensen, M. C., \& Meckling, W. (1976). Theory of the Firm: Managerial Behavior, Agency Costs, and Capital Structure. Journal of Financial Economics, 3(4), 305-360.

https://doi.org/10.1016/0304-405X(76)90026-X

Kor, Y. Y., \& Sundaramuthy, G. (2009). Experience-based Human Capital and Social Capital of Outside Directors. Journal of Management, 35(4), 981-1006.

https://doi.org/10.1177/0149206308321551

Kothari, S. P., \& Zimmerman, J. L. (1995). Price and Return Models. Journal of Accounting and Economics, 20(2), 155-192. https://doi.org/10.1016/0165-4101(95)00399-4

Kuo, H. C., Yeh, L. J., \& Wang, L. H. (2016). The Role of Corporate Governance in the Financial Performance of R\&D Investment: A Non-linear Relationship by U-shape Test. Review of Securities and Futures Markets, 28(4), 1-48. 
Kuo, H. C., Yeh, L. J., \& Wang, L. H. (2018). The role of education of Directors in influencing firm R\&D investment. Asia Pacific Management Review, 23(2), 108-120.

https://doi.org/10.1016/j.apmrv.2017.05.002

Kwon, G. J. (2014). The Role of R\&D Investment in Firm Valuation for Small and Medium Korean Companies. Asian Social Science, 10(15), 169-186.

https://doi.org/10.5539/ass.v10n15p169

Le, S. A., Walter, B. \& Kroll, M. (2006). The Moderating Effects of External Monitors on the Relationship between R\&D Spending and Firm Performance. Journal of Business Research, 59(2), 278-287. https://doi.org/10.1016/j.jbusres.2005.04.003

Lee, C. F., Liang, W. L., Lin, F. L., \& Yang, Y. (2016). Applications of Simultaneous in Finance Research: Methods and Empirical Results. Review of Quantitative Finance and Accounting, 47, 943-971. https://doi.org/10.1007/s11156-015-0526-0

Mahadeo, J. D., Soobaroyen, T., \& Hanuman, V. O. (2012). Board Composition and Financial Performance: Uncovering the Effects of Diversity in an Emerging Economy. Journal of Business Ethics, 105(3), 375-388. https://doi.org/10.1007/s10551-011-0973-z

Morck, R., Shleifer, A., \& Vishny, R. W. (1988). Management Ownership and Market Valuation: An Empirical Analysis. Journal of Financial Economics, 20(1-2), 293-315.

https://doi.org/10.1016/0304-405X(88)90048-7

Patterson, M. L. (1998). From Experience: Linking Product Innovation to Business Growth. Journal of Product Innovation Management, 15(5), 390-402.

https://doi.org/10.1111/1540-5885.1550390

Ren, H., Chandrasekar, K., \& Li, B. (2012). Moderating Effects of Board and Managerial Incentive on the Relationship Between R\&D Investment and Firm Performance-evidence from Listed Manufacturing Firms in China. The Journal of International Management Studies, 7(1), 41-55.

Saad, M., \& Zantout, Z. (2014). Over-investment in Corporate R\&D, Risk and Stock Returns. Journal of Economics and Finance, 38(3), 438-460.

https://doi.org/10.1007/s12197-012-9226-y

Schimke, A., \& Brenner, T. (2014). The Role of R\&D Investments in highly R\&D-based Forms. Studies in Economics and Finance, 31(1), 3-45.

https://doi.org/10.1108/SEF-02-2012-0017

Sougiannis, T. (1994). The Accounting Based Valuation of Corporate R\&D. The Accounting Review, 69(1), 44-68.

Sweeney, R., Warga, A. D., \& Winters, D. (1997). The Market Value of Debt, Market versus Book Value of Debt, and Returns to Assets. Financial Management, 26(1), 5-21.

https://doi.org/10.2307/3666236

Wang, C. H. (2011). Clarifying the Effects of R\&D on Performance: Evidence from the High 


\section{Macrothink}

Business and Economic Research

ISSN 2162-4860

2021, Vol. 11, No. 2

Technology Industries. Asia Pacific Management Review, 16(1), 51-64.

Wincent, J., Anokhin, S., \& Ortqvist, D. (2010). Does Network Board Capital Matter? A Study of Innovative Performance in Strategic SME Network. Journal of Business Research, 63(3), 265-275. https://doi.org/10.1016/j.jbusres.2009.03.012

\section{Copyright Disclaimer}

Copyright for this article is retained by the author(s), with first publication rights granted to the journal.

This is an open-access article distributed under the terms and conditions of the Creative Commons Attribution license (http://creativecommons.org/licenses/by/4.0/). 